\title{
Synthesis of Chiral Methyl Cucurbate and Its Analogs
}

\author{
Jun TaKehara, Takayuki Oritani* and Kyohei Yamashita \\ Department of Agricultural Chemistry, Faculty of Agriculture, \\ Tohoku University, Aoba-ku, Sendai 981, Japan
}

Received April 30, 1991

\begin{abstract}
Natural $(+)-(1 R, 2 S, 3 S)$-methyl cucurbate $(1 b)$ and the $(-)-\delta$-lactone of 3-epi-cucurbic acid (16) were synthesized from $(+)-(1 R, 6 S, 7 R)$-bicyclo[4.3.0]non-3-en-7-ol (5). Asymmetric hydrolysis of the acetate $(8)$ of $( \pm)-5$ with pancreatin gave optically pure the $(+)-(7 R)$-alcohol $(5)$ and $(-)-(7 S)$ acetate (8). An ozonolysis product of $(+)-5$ was transformed to $(-)-16$ and $(+)-(3 S)-1 b$ with inversion of the (7R)-hydroxyl group. Similarly, unnatural $(-)$-1b and $(+)-16$ were prepared from optically pure $(-)-5$. The growth inhibitory activities of these synthesized chiral compounds toward lettuce seedlings were examined.
\end{abstract}

Cucurbic acid (1a) has been isolated from seeds of Cucurbita pepo L. as a plant growth inhibitor." ${ }^{1)}$ This compound has a skeleton similar to jasmonic acid (2a), methyl jasmonate (2b) and methyl epi-jasmonate (3), which have also been found as plant growth regulators. ${ }^{2,3)}$ The structure-activity relationships of $\mathbf{2 a}$ and $\mathbf{2 b}$ have been investigated in detail without those of 1a. ${ }^{3)}$ Here, we described the first synthesis of both enantiomers of methyl cucurbate (1b) and their effects on the growth of lettuce seedlings.

Our synthetic plan for chiral 1b depended on the enzymatic preparation of chiral $(1 R, 6 S, 7 R)$-bicyclo-[4.3.0]-non-3-en-7-ol (5). Racemic 5 has often been used for the synthesis of various natural cyclopentanoids; $( \pm)$ methyl jasmonate $(\mathbf{2 b})$ and $( \pm)$-methyl epijasmonate (3) were synthesized by $\mathrm{H}$. Tanaka and S. Torii in $1975^{5)}$ and the $(+)$-tuberolide by B. Mauer and A. Hauser in 1982. ${ }^{6)}$ In order to synthesize natural $\mathbf{1 a}$ with the $(3 S)$-hydroxyl
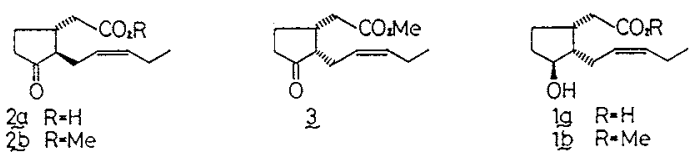

Fig. 1 group from chiral $(7 R)-\mathbf{5}$, it is necessary to invert the configuration of the hydroxyl group in substrate 5. Already, T. Kitahara et al. have synthesized ( \pm )-methyl cucurbate (1b) based on selective hydroboration of a cyclopentene intermediate. ${ }^{7)}( \pm)$-Bicyclo[4.3.0]non-3-en-7-on $\left.(4)^{6}\right)$ (cis: trans $=9: 1$ ) was reduced with $\mathrm{NaBH}_{4}$ in the presence of $\mathrm{CeCl}_{3}$. $7 \mathrm{H}_{2} \mathrm{O}$ in methanol to give a stereoisomeric mixture of four alcohols: 1,6-cis,6,7-cis-5 $(84 \%), 1,6-c i s, 6,7-$ trans-6 $(6 \%)$, and the $1,6-$ trans,6,7-cis- and 1,6-trans,6,7-trans-isomers $(10 \%)$. Attempts to separate these isomers by silica gel chromatography failed. Thus, ( \pm )-5 was separated from the mixture by treating it with $\mathrm{N}$-bromosuccinimide (NBS) in dry THF, which, after chromatographic separation, gave the bromoether (7). Reduction of 7 with $\mathrm{Zn} / \mathrm{NH}_{4} \mathrm{Cl}$ gave the pure alcohol (5), which was acetylated with acetic anhydride-pyridine to yield the $( \pm)$-acetate $(\mathbf{8})$. Microbial hydrolysis of $( \pm)-8$ with Bacillus subtilis subsp. niger gave the (+)-alcohol (5) with low optical purity. However, $( \pm)-8$ was asymmetrically hydrolyzed with pancreatin to yield the $(+)$-alcohol $(5)$ and $(-)$-acetate $(8)$ with more than a $94 \%$ enantiomeric excess (e.e.). Deacetylation of $(-)-8$ with methanolic $\mathrm{KOH}$ gave the (-)-alcohol (5). The optical purity was determined by ${ }^{1} \mathrm{H}-\mathrm{NMR}$ analysis 

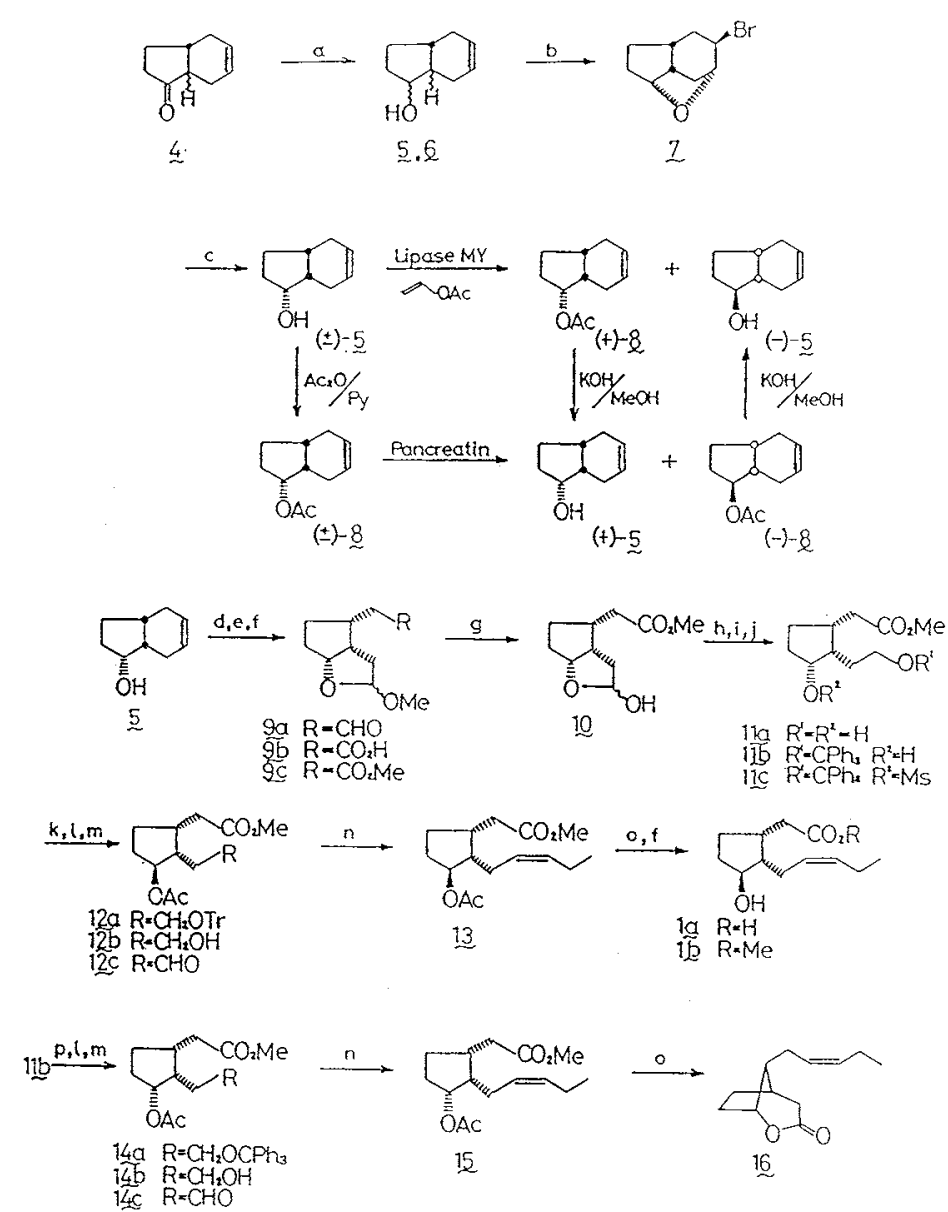

Scheme 1. a) $\mathrm{NaBH}_{4}, \mathrm{CeCl}_{3}, \mathrm{MeOH},-70 \mathrm{C}(95 \%)$. b) NBS, THF (83\%). c) Zn, $\mathrm{NH}_{4} \mathrm{Cl}$, EtOH $(76 \%)$. d) $\mathrm{O}_{3}, \mathrm{MeOH} \cdots \mathrm{CH}_{2} \mathrm{Cl}_{2},-70^{\circ} \mathrm{C} ; \mathrm{PPh}_{3}$, RT (95\%). e) $\mathrm{KMnO}_{4}, \mathrm{MgSO}_{4}$, acetone, $(66 \%)$. f) $\mathrm{CH}_{2} \mathrm{~N}_{2}(100 \%)$. g) $30 \% \mathrm{AcOH}, 60^{\circ} \mathrm{C}$, (77\%). h) $\mathrm{NaBH}_{4}, \mathrm{CeCl}_{3}, \mathrm{MeOH}$, (84\%). i) $\mathrm{Ph}_{3} \mathrm{CCl}, \mathrm{Py}, \mathrm{DMAP},(91 \%)$. j) $\mathrm{MsCl}, \mathrm{Py}$, DMAP, RT. k) AcOK, 18-crown-6, benzene, reflux (42\% from 1lb). 1) p-TsOH, MeOH, RT (71\%). m) $\mathrm{PDC}, \mathrm{CH}_{2} \mathrm{Cl}_{2}$, RT (62\%). n) $\mathrm{Ph}_{3} \mathrm{P}(\mathrm{Pr}) \mathrm{Br}, \mathrm{NaNH}_{2}$, benzene $(64 \%)$. o) $1 \mathrm{~N} \mathrm{NaOH}, \mathrm{MeOH}-\mathrm{H}_{2} \mathrm{O}, 40^{\circ} \mathrm{C}$; $10 \% \mathrm{HCl}(87 \%)$. p) $\mathrm{Ac}_{2} \mathrm{O}$, Py, DMAP (100\%).

of the $(S)-(-)$-MTPA esters of each chiral alcohol which were shifted by $\mathrm{Eu}(\mathrm{fod})_{3}$.

Enzymatic acetylation of $( \pm)-5$ with vinyl acetate in an organic solvent gave the $(+)$-acetate $(\mathbf{8})$ with high optical purity as shown in Table I.

Chiral alcohol (+)-5 was cleaved by ozonolysis in methanol at $70^{\circ} \mathrm{C}$ and then reduced with triphenylphosphine to give the (+)-aldehyde (9a), which was then oxidized with $\mathrm{KMnO}_{4}$, and esterified with diazomethane to yield methyl ester $(+)-9 c$. Hydrolysis of $(+)-9 \mathrm{c}$ with $50 \%$ acetic acid at $60^{\circ} \mathrm{C}$ gave the $(+)$-lactol $(10)$ in a $60 \%$ overall yield from (+)-5. Lactol 10 was reduced with $\mathrm{NaBH}_{4}$ in the presence of $10 \% \mathrm{CeCl}_{3} \cdot 7 \mathrm{H}_{2} \mathrm{O}$ in methanol to give the $(+)$-diol (11a). The prim-hydroxyl group of $(+)$-11a was selectively protected with trityl chloride to give the $(+)$-trityl ether $(\mathbf{1 1 b})$, whose sec-hydroxyl group was then transformed to the mesylate (11c). This $(3 R)$-11c was treated with AcOK and 18-crown-6 in refluxing benzene to give the $(-)-(3 S)$-acetate (12a) with $S_{\mathrm{N}} 2$ inversion in a $47 \%$ yield $^{8)}$; the same amount of the eliminated product was observed. The reaction of 11c with AcOK in 
Table I. Enzymatic Resolution of ( \pm )-Acetate 8 and ( \pm )-Alcohol 5

\begin{tabular}{|c|c|c|c|c|c|}
\hline $\begin{array}{c}\text { Microorganism or } \\
\text { enzyme }\end{array}$ & $\begin{array}{l}\text { Concentration of } \\
\text { substrate }(\%)\end{array}$ & $\begin{array}{l}\text { Temp. } \\
\left({ }^{\circ} \mathrm{C}\right)\end{array}$ & $\begin{array}{l}\text { Time } \\
\text { (hr) }\end{array}$ & $\begin{array}{c}\text { Ratio of } \\
\text { hydrolysis }(\%)\end{array}$ & $\begin{array}{l}\text { Optical purity } \\
(\% \text { e.e. })\end{array}$ \\
\hline $\begin{array}{l}\text { Bacillus subtilis } \\
\text { subsp. niger IFO } 3108\end{array}$ & 1.5 & 30 & 58 & 26 & 54 \\
\hline $\begin{array}{l}\text { Pancreatin } \\
\text { (from porcine source) }\end{array}$ & 0.5 & 30 & $72-480$ & $\leqq 40$ & $\geqq 95$ \\
\hline Enzyme & $\begin{array}{l}\text { Concentration of } \\
\text { substrate }(\%)\end{array}$ & $\begin{array}{l}\text { Temp. } \\
\left({ }^{\circ} \mathrm{C}\right)\end{array}$ & $\begin{array}{l}\text { Time } \\
\text { (hr) }\end{array}$ & $\begin{array}{l}\text { Rate of acylation } \\
\qquad(\%)\end{array}$ & $\begin{array}{l}\text { Optical purity } \\
(\% \text { e.e. })\end{array}$ \\
\hline Amano $\mathrm{P}^{a}$ & 3.3 & 30 & 16 & 48 & 82 \\
\hline Amano $\mathrm{P}^{a}$ & 3.3 & 30 & 40 & 36 & 84 \\
\hline Lipase $\mathrm{MY}^{b}$ & 3.3 & 30 & 40 & 29 & 100 \\
\hline Pancreatin $^{c}$ & 3.3 & 30 & 42 & - & - \\
\hline
\end{tabular}

a Amano P was from Pseudomonas sp.

$b$ Lipase MY was from Candida cylindracea.

c Pancreatin was from porcine pancreas.

$\mathrm{DMF}^{10)}$ and a Mitsunobu reaction ${ }^{8)}$ of $\mathbf{1 1 c}$ gave only the eliminated product. The $(-)$-acetate $(\mathbf{1 2 a})$ was detritylated by treating with $p$-toluenesulfonic acid $(p-\mathrm{TsOH})$ in methanol to give the (-)-alcohol $(\mathbf{1 2 b})$, which was then oxidized with pyridinum dichromate (PDC) in $\mathrm{CH}_{2} \mathrm{Cl}_{2}$ to obtain the (3S)-aldehyde (12c). A Wittig reaction of $(3 S)$-12c with propylidenetriphenylphosphorane under saltfree conditions ${ }^{11)}$ in benzene gave the olefine (13) in a $60 \%$ yield. Alkaline hydrolysis of $\mathbf{1 3}$ gave $(+)$-cucurbic acid (1a), whose physical data and spectral data ${ }^{7)}$ were agreed with those of the natural product. Methylation of $(+)-1$ a with diazomethane gave $(+)$-methyl cucurbate (1b). As a result, natural (+)-cucurbic acid (1a) with the $(1 R, 2 S, 3 S)$-configuration was synthesized from chiral synthon $(+)-5$. This shows that $(+)-\mathbf{5}$ had the $(1 R, 6 S, 7 R)$-configuration, and enzymatic hydrolysis of substrate $( \pm)-5$ by various lipase gave the $(7 R)$-alcohol (5) and $(7 S)$-acetate $(\mathbf{8})$ as was expected from our previous result. ${ }^{4)}$ Furthermore, methyl 3-epi3-O-acetoxy cucurbate (15) was synthesized from $(+)-\mathbf{1 1 b}$. Acylation of $(+)-\mathbf{1 1 b}$, with subsequent detritylation with $p-\mathrm{TsOH}$ in methanol, gave the $(-)$-alcohol $(\mathbf{1 4 b})$. Oxida-
Table II. InHibitory Effects of Chiral Methyl Cucurbate and Its Analogs on the Growth of Lettuce SeEdlings (cv. Great Lakes)

\begin{tabular}{|c|c|c|c|c|}
\hline \multirow{2}{*}{ Compound } & \multicolumn{4}{|c|}{ Root length (\% of the control) } \\
\hline & I ppm & $10 \mathrm{ppm}$ & $50 \mathrm{ppm}$ & $100 \mathrm{ppm}$ \\
\hline$(+)-16$ & 39 & 33 & 25 & 25 \\
\hline$(-)-\mathbf{1 b}$ & 90 & 87 & 67 & 70 \\
\hline$( \pm)-1 b$ & 70 & 56 & 56 & 49 \\
\hline$( \pm)-1 a$ & 52 & 42 & 38 & 27 \\
\hline$(-)-16$ & 88 & 86 & 87 & 73 \\
\hline$(+)-16$ & 78 & 91 & 84 & 59 \\
\hline$( \pm)-16$ & 88 & 84 & 96 & 69 \\
\hline$( \pm)-2 b$ & 74 & 16 & 8 & 2 \\
\hline
\end{tabular}

tion of (-)-14b with PDC gave the aldehyde (14c), which was reacted with propylidenetriphenylphosphorane to yield the acetate (15). Alkaline hydrolysis of $\mathbf{1 5}$ and subsequent acidification with dilute $\mathrm{HCl}$ gave 3-epicucurbic acid (16) as (-)- $\delta$-lactone form $\mathbf{1 6}$. Similarly, unnatural (-)-cucurbic acid (1a) and $(+)$ - $\delta$-lactone $(16)$ were synthesized from the $(-)$-chiral synthon (5).

Finally, the growth inhibitory activities of the synthesized compounds were examined by using lettuce seedlings (cv. Great Lakes) (Table 
II). In consequence, cucurbic acid (1a) and its methyl ester (1) inhibited the growth of lettuce seedlings; however, the 3-epimer (16) had no effect in this test. Furthermore, natural $(+)-\mathbf{1 b}$ showed stronger activity than that of unnatural (-)-1b.

\section{Experimental}

All melting points (mp) and boiling points (bp) are uncorrected. IR spectra were recorded on a JASCO IR-810 infrared spectrometer, while ${ }^{1} \mathrm{H}-\mathrm{NMR}$ spectra were recorded on a JEOL GSX-270 spectrometer at $270 \mathrm{MHz}$ or JEOL JNM FX-100 spectrometer, with mass spectra being measured with a JEOL JMS-HX-105.

$( \pm)-\left(I R^{*}, 6 S^{*}, 7 R^{*}\right)$-Bicyclo[4.3.0]non-3-en-7-ol (5). To a stirred mixture of ketones 4 (cis: trans $=93: 7,29.73 \mathrm{~g}$, $0.22 \mathrm{~mol})$ and $\mathrm{CeCl}_{3} \cdot 7 \mathrm{H}_{2} \mathrm{O}(8.20 \mathrm{~g}, 0.02 \mathrm{~mol})$ in $400 \mathrm{ml}$ of methanol was slowly added $\mathrm{NaBH}_{4}(8.20 \mathrm{~g}, 0.24 \mathrm{~mol})$ at $-70^{\circ} \mathrm{C}$. After stirring for $1 \mathrm{hr}$ at the same temperature, the reaction mixture was quenched by adding dilute $\mathrm{HCl}$ and concentrated in vacuo. The residue was extracted with ether. The organic extract was washed with aq. $\mathrm{NaHCO}_{3}$ and brine, and dried over $\mathrm{MgSO}_{4}$. Evaporation of the extract gave alcohols consisting of four stereoisomers $(28.85 \mathrm{~g}, 95 \%$ yield). To this mixture $(28.85 \mathrm{~g}, 0.21 \mathrm{~mol})$ in $300 \mathrm{ml}$ of dry tetrahydrofurane (THF) was added $\mathrm{N}$ bromosuccinimde (NBS; $31.77 \mathrm{~g}, 0.18 \mathrm{~mol}$ ) at $0^{\circ} \mathrm{C}$. After stirring overnight, the reaction mixture was poured into ice-cooled water and extracted with ether. The ether extract was dried over $\mathrm{MgSO}_{4}$ and then evaporated. The residual oil was chromatographed on $\mathrm{SiO}_{2}$ to give bromoether 7 $\left(32.30 \mathrm{~g}, 83 \%\right.$ yield). IR $v_{\max } \mathrm{cm}^{-1}: 2950,1280,1225,680$. ${ }^{1} \mathrm{H}-\mathrm{NMR}\left(\mathrm{CDCl}_{3}\right) \delta: 1.30-2.60(10 \mathrm{H}, \mathrm{m}), 3.70-4.50(3 \mathrm{H}$, m). A mixture of $7(32.30 \mathrm{~g}, 0.15 \mathrm{~mol}), \mathrm{NH}_{4} \mathrm{Cl}(58.84 \mathrm{~g}$, $1.10 \mathrm{~mol})$ and zinc powder $(58.84 \mathrm{~g}, 0.90 \mathrm{~mol})$ in $300 \mathrm{ml}$ of $95 \%$ ethanol was stirred under reflux for $5 \mathrm{hr}$. After filtration and concentration, the residue was extracted with ether, and the ethereal layer washed with brine and then dried. Removal of the solvent gave $15.64 \mathrm{~g}(76 \%)$ of pure (士)-5, bp $80^{\circ} \mathrm{C} / 5 \mathrm{mmHg}$. IR $v_{\max } \mathrm{cm}^{-1}: 3350,3025,1660$, $1438,1100,1008 .{ }^{1} \mathrm{H}-\mathrm{NMR}\left(\mathrm{CDCl}_{3}\right) \delta: 1.40-2.40(11 \mathrm{H}$, $\mathrm{m}), 4.20-4.40(1 \mathrm{H}, \mathrm{m}), 5.60-5.90(2 \mathrm{H}, \mathrm{m})$. EI-MS $(\mathrm{m} / \mathrm{z})$ : $138\left(\mathrm{M}^{+}, 2\right), 120(94), 105(29), 91(100)$.

(土)-( $\left(1 R^{*}, 6 S^{*}, 7 R^{*}\right)$-Bicyclo[4.3.0]non-3-en-7-yl acetate (8). To a solution of $5(3.20 \mathrm{~g}, 23.2 \mathrm{mmol})$ and $\mathrm{Ac}_{2} \mathrm{O}(8.29 \mathrm{~g}$, $81.2 \mathrm{mmol}$ ) in $50 \mathrm{ml}$ of dry benzene, $6.41 \mathrm{~g}$ of pyridine $(81.2 \mathrm{mmol})$ and $100 \mathrm{mg}$ of 4-dimethylaminopyridine (DMAP) were added at room temperature under nitrogen. After stirring overnight, the reaction mixture was poured into ice-cooled water and extracted with ether. The organic layer was successively washed with dilute $\mathrm{HCl}$, aq. $\mathrm{NaHCO}_{3}$ and brine, dried and then evaporated. Distillation of the residue gave $( \pm)$-acetate $\mathbf{8}$, bp $89-92^{\circ} \mathrm{C} / 7 \mathrm{mmHg}$. IR $v_{\max }\left(\mathrm{cm}^{-1}\right): 3030,1740,1660,1378$, 1255, 1085. ${ }^{1} \mathrm{H}-\mathrm{NMR}\left(\mathrm{CDCl}_{3}\right) \delta: 1.27-2.40(10 \mathrm{H}, \mathrm{m}), 2.02$ $(3 \mathrm{H}, \mathrm{s}), 5.05-5.30(1 \mathrm{H}, \mathrm{m}), 5.55-5.75(2 \mathrm{H}, \mathrm{m})$. EI-MS $(m / z)$ : $180\left(\mathrm{M}^{+}, 5\right), 121(58), 120(54), 105(28), 91(100)$.

Asymmetric hydrolysis of $( \pm)$-acetate 8 with pancreatin. A mixture of $( \pm)-8(0.50 \mathrm{~g}, 2.78 \mathrm{mmol}), \mathrm{CaCl}_{2}(0.10 \mathrm{~g})$ and crude pancreatin $(2.00 \mathrm{~g}$ of powder from porcine pancreas; Nacalai Tesque-Inc., Japan) in $100 \mathrm{ml}$ of pH 7.0-phosphate buffer was vigorously stirred at $30^{\circ} \mathrm{C}$ for $3-20$ days. The reaction mixture was steam-distilled, and the distillate was saturated with brine and extracted with ether. The ethereal extract was dried and concentrated. The residual oil was chromatographed on silica gel to give ( - -acetate $(8)$ and optically pure ( +$)-5, \operatorname{mp} 43-44^{\circ} \mathrm{C},[\alpha]_{\mathrm{D}}^{22}+15.7^{\circ}(c=1.17$, $\mathrm{CHCl}_{3}$; after recrystallization from hexane). Alkaline hydrolysis of (-)-8 and subsequent followed by crystallization from hexane, gave $(-)-5, \mathrm{mp} 44-45^{\circ} \mathrm{C},[\alpha]_{\mathrm{D}}^{22}$ $+14.9^{\circ}\left(c=0.68, \mathrm{CHCl}_{3}\right)$.

Asymmetric acetylation of $( \pm)-\mathbf{5}$ with lipase $M Y$. A mixture of $( \pm)-5(0.10 \mathrm{~g}, 0.72 \mathrm{mmol})$, vinyl acetate $(0.06 \mathrm{~g}$, $0.72 \mathrm{mmol})$ and lipase MY $(0.05 \mathrm{~g}$ as powder from Meito Sangyo Co., Ltd.) in $5 \mathrm{ml}$ of hexane was stirred at $30^{\circ} \mathrm{C}$ for $40 \mathrm{hr}$. After filtration and evaporation, the residual oil was chromatographed on $\mathrm{SiO}_{2}$ to give $(+)$-acetate 8 . Hydrolysis of $(+)-8$ with methanolic $\mathrm{KOH}$ gave optically pure $(+)-5(0.03 \mathrm{~g}, 0.21 \mathrm{mmol}, 29 \%$ yield $)$.

$(I R, 5 S, 6 R)-6$-formylmethyl-3-methoxy-2-oxabicyclo[3.3.0]octane (9a). A solution of $(+)-5(2.88 \mathrm{~g}, 20.87$ mmol) in $120 \mathrm{ml}$ of methanol and $\mathrm{CH}_{2} \mathrm{Cl}_{2}(1: 1)$ was ozonized at $-70^{\circ} \mathrm{C}$. After nitrogen had been bubbled into the reaction solution to remove the excess ozone, $5.47 \mathrm{~g}$, of $\mathrm{Ph}_{3} \mathrm{P}(20.87 \mathrm{mmol})$ was added to the solution, which was then stirred overnight at room temperature. The mixture was concentrated and chromatographed on $\mathrm{SiO}_{2}$ to give aldehyde $9 \mathrm{a}\left(3.64 \mathrm{~g}, 95 \%\right.$ yield). IR $v_{\max } \mathrm{cm}^{-1}$ : $2730,1725,1095,1045,1020,920 .{ }^{1} \mathrm{H}-\mathrm{NMR}\left(\mathrm{CDCl}_{3}, 3-\beta\right.$ form) $\delta: 1.40-3.00(10 \mathrm{H}, \mathrm{m}), 3.30(3 \mathrm{H}, \mathrm{s}), 4.68(1 \mathrm{H}, \mathrm{m})$, $4.90(1 \mathrm{H}, \mathrm{d}, \mathrm{d}, J=5.1,1.7 \mathrm{~Hz}), 9.80(1 \mathrm{H}, \mathrm{t}, J=1.5 \mathrm{~Hz})$.

(IR,5S,6R)-6-Methoxycarbonylmethyl-3-methoxy-2oxabicyclo[3.3.0] octane $(9 \mathrm{c})$. To a solution of $9 \mathrm{a}(0.29 \mathrm{~g}$, $1.58 \mathrm{mmol})$ in $60 \mathrm{ml}$ of acetone was added a solution of $\mathrm{KMnO}_{4}(0.25 \mathrm{~g}, 1.58 \mathrm{mmol})$ and $\mathrm{MgSO}_{4}(0.19 \mathrm{~g}, 1.58$ $\mathrm{mmol})$ in $6 \mathrm{ml}$ of water. The mixture was stirred for $5 \mathrm{hr}$ at $0^{\circ} \mathrm{C}$, and $30 \mathrm{ml}$ of 2-propanol was then added. After stirring for a few more hours at room temperature, the reaction mixture was filtered, and the filtrate was concentrated. The residue was acidified and extracted with $\mathrm{CHCl}_{3}$. The extract was dried and concentrated to give an oily acid $(0.21 \mathrm{~g})$, which was methylated with diazomethane to give methyl ester $9 \mathrm{c}\left(0.18 \mathrm{~g}, 100 \%\right.$ yield). IR $v_{\max } \mathrm{cm}^{-1}$ : $1740,1095,1045,1000 .{ }^{1} \mathrm{H}-\mathrm{NMR}\left(\mathrm{CDCl}_{3}\right) \delta: 1.20-3.10$ $(10 \mathrm{H}, \mathrm{m}), 3.29(3 \mathrm{H}, \mathrm{s}), 3.67(3 \mathrm{H}, \mathrm{s}), 4.60(1 \mathrm{H}, \mathrm{m}), 4.99$ $(1 \mathrm{H}, \mathrm{d}, J=4.4 \mathrm{~Hz}$. 
$(+)-(1 R, 2 S, 3 R)-$ Methyl-3-hydroxy-2-(2-hydroxyethyl)1-cyclopentaneacetate (11a). A mixture of methyl ester $9 \mathrm{c}$ $(0.18 \mathrm{~g}, 0.84 \mathrm{mmol})$ and $50 \mathrm{ml}$ of $30 \% \mathrm{AcOH}$ was stirred at $60^{\circ} \mathrm{C}$ for $0.5 \mathrm{hr}$. The mixture was neutralized with $\mathrm{NaHCO}_{3}$ and extracted with $\mathrm{CHCl}_{3}$. The extract was dried and concentrated to give $(1 R, 5 S, 6 R)$-6-methoxycarbonylmethyl-3-hydroxy-2-oxabicyclo[3.3.0]octane (10) as an oil $\left(0.13 \mathrm{~g}, 77 \%\right.$ yicld). IR $v_{\max } \mathrm{cm}^{-1}: 3420,1740,1440,1200$, $1035,1025 .{ }^{1} \mathrm{H}-\mathrm{NMR}\left(\mathrm{CDCl}_{3}\right) \delta: 1.10-3.20(10 \mathrm{H}, \mathrm{m}), 3.29$ ( $1 \mathrm{H}$, br, disappeared by $\mathrm{D}_{2} \mathrm{O}$ exchange), $3.68(3 \mathrm{H}, \mathrm{s}), 4.7 \mathrm{I}$ $(1 \mathrm{H}, \mathrm{m}), 5.54(\mathrm{lH}, \mathrm{d}, J=4.4 \mathrm{~Hz})$. To a mixture of $10(0.99 \mathrm{~g}$, $4.95 \mathrm{mmol})$ and $\mathrm{CeCl}_{3} \cdot 7 \mathrm{H}_{2} \mathrm{O}(0.35 \mathrm{~g}, 0.50 \mathrm{mmol})$ in $20 \mathrm{ml}$ of methanol was added $\mathrm{NaBH}_{4}(0.75 \mathrm{~g}, 19.8 \mathrm{mmol})$ at $-10^{\circ} \mathrm{C}$, the mixture being stirred for $5 \mathrm{hr}$. This mixture was acidified with acetic acid and concentrated in vacuo. The residue was chromatographed over $\mathrm{SiO}_{2}$ to give $(+)-11 \mathrm{a}(0.84 \mathrm{~g}, 84 \%$ yield $),[\alpha]_{\mathrm{D}}^{23}+15.9^{\circ} \quad(c=1.37$, $\left.\mathrm{CHCl}_{3}\right) . \mathrm{IR} v_{\text {max }} \mathrm{cm}^{-1}: 3400,1738,1438,1200,1170,1040$. ${ }^{1} \mathrm{H}-\mathrm{NMR}\left(\mathrm{CDCl}_{3}\right)$ \&: $1.52-2.03(7 \mathrm{H}, \mathrm{m}), 2.38-2.55(3 \mathrm{H}$, $\mathrm{m}), 2.50-3.00\left(2 \mathrm{H}\right.$, br, disappeared by $\mathrm{D}_{2} \mathrm{O}$ exchange), 3.69 $(3 \mathrm{H}, \mathrm{s}), 3.66-3.75(1 \mathrm{H}, \mathrm{m}), 3.83-3.90(1 \mathrm{H}, \mathrm{m}), 4.32(1 \mathrm{H}$, $\mathrm{t}, \mathrm{d}, J=2.7,5.4 \mathrm{~Hz})$. Anal. Found: C, 59.10; H, 9.12. Calcd. for $\mathrm{C}_{10} \mathrm{H}_{18} \mathrm{O}_{4}: \mathrm{C}, 59.39 ; \mathrm{H}, 8.97 \%$. Similarly, (-)-11a was prepared from $(-)-5,[\alpha]_{\mathrm{D}}^{23}-17.6^{\circ}\left(c=1.03, \mathrm{CHCl}_{3}\right)$.

$(+)-(I R, 2 S, 2 R)-$ Methyl 3-hydroxy-2-(2-triphenylmethoxyethyl)-1-cyclopentaneacetate (11b). To a solution of (-)-11a (64 mg, $0.32 \mathrm{mmol})$ and trityl chloride $(128 \mathrm{mg}$, $0.48 \mathrm{mmol}$ ) in $3 \mathrm{ml}$ of dry $\mathrm{CH}_{2} \mathrm{Cl}_{2}$ was added pyridine (38 $\mathrm{mg}, 0.48 \mathrm{mmol}$ ) and $10 \mathrm{mg}$ of DMAP under $\mathrm{N}_{2}$. After refluxing overnight, the reaction mixture was concentrated in vacuo and chromatoraphed on $\mathrm{SiO}_{2}$ to give $(+)-\mathbf{1 1 b}$ (129 mg, 91\% yield $) .[\alpha]_{\mathrm{D}}^{23}+28.2^{\circ}\left(c=1.87, \mathrm{CHCl}_{3}\right) \cdot \mathrm{IR}$ $v_{\max } \mathrm{cm}^{-1}: 3600,1735,1595,1448,1070,705 .{ }^{1} \mathrm{H}-\mathrm{NMR}$ $\left(\mathrm{CDCl}_{3}\right) \delta: 1.30-3.40(12 \mathrm{H}, \mathrm{m}), 3.64(3 \mathrm{H}, \mathrm{s}), 4.13(1 \mathrm{H}, \mathrm{m})$, 7.10-7.50 (15H, m). Anal. Found: C, 78.15; H, 7.46. Caled. for $\mathrm{C}_{29} \mathrm{H}_{32} \mathrm{O}_{4}: \mathrm{C}, 78.35 ; \mathrm{H}, 7.25 \%$.

$(+)-(I R, 2 S, 2 S)-$ Methyl-3-acetoxy-2-(2-triphenylmethoxyethyl)-1-cyclopentaneacetate (12a). A mixture of (+)-11b (199 mg, 0.45 mmol), MsCl $(0.21 \mathrm{~g}, 2.69 \mathrm{mmol})$, pyridine $(0.21 \mathrm{~g}, 2.69 \mathrm{mmol})$ and $10 \mathrm{mg}$ of DMAP in $5 \mathrm{ml}$ of $\mathrm{CH}_{2} \mathrm{Cl}_{2}$ was stirred at room temperature under $\mathrm{N}_{2}$ overnight. The reaction mixture was poured into water and extracted with $\mathrm{CH}_{2} \mathrm{Cl}_{2}$. The extract was washed with aq. $\mathrm{CuSO}_{4}$, aq. $\mathrm{NaHCO}_{3}$ and brine, dried over $\mathrm{CaCl}_{2}$, and then concentrated at room temperature. This crude methanesulfonate, $\mathrm{AcOK}(0.57 \mathrm{~g}, 5.85 \mathrm{mmol})$ and 18 crown-6 $(0.24 \mathrm{~g}, 0.9 \mathrm{mmol})$ was dissolved in $10 \mathrm{ml}$ dry benzene. After stirring vigorously under reflux overnight, the reaction mixture was filtrated and evaporated. The residue was chromatographed on $\mathrm{SiO}_{2}$ to give $(+)-\mathbf{1 2 a}$ $(93 \mathrm{mg}, 42 \%$ yield from $(+)-11 \mathrm{~b}) .[\alpha]_{\mathrm{D}}^{23}+13.3^{\circ}(c=1.87$, $\left.\mathrm{CHCl}_{3}\right)$. IR $v_{\max } \mathrm{cm}^{-1}: 3060,1738,1595,1245,1070,708$. ${ }^{1} \mathrm{H}-\mathrm{NMR}\left(\mathrm{CDCl}_{3}\right) \delta: 1.26-2.18(7 \mathrm{H}, \mathrm{m}), 1.94(3 \mathrm{H}, \mathrm{s}), 2.15$ $(\mathrm{lH}, \mathrm{d}, \mathrm{d}, J=15.4,10.0 \mathrm{~Hz}), 2.37(1 \mathrm{H}, \mathrm{d}, \mathrm{d}, J=7.8,3.7$, $3.7 \mathrm{~Hz}), 7.20-7.45(15 \mathrm{H}, \mathrm{m})$. Anal. Found: C, 76.29; H,
7.05. Calcd. for $\mathrm{C}_{31} \mathrm{H}_{34} \mathrm{O}_{5}: \mathrm{C}, 76.52 ; \mathrm{H}, 7.04 \%$.

(-)-(1R,2S,3S)-Methyl 3-acetoxy-2-(2-hydroxyethyl)1-cyclopentaneacetate (12b). A mixture of $(+)-12 a(180 \mathrm{mg}$, $0.37 \mathrm{mmol}$ ) and $18 \mathrm{mg}$ of $p-\mathrm{TsOH}$ in $15 \mathrm{ml}$ of methanol was stirred at room temperature for $3 \mathrm{hr}$, and then neutralized with aq. $\mathrm{NaHCO}_{3}$. After concentrating in vacuo, the resicue was chromatographed on $\mathrm{SiO}_{2}$ to give $(-)-\mathbf{1 2} \mathbf{b}$ $(64 \mathrm{mg}, 71 \%$ yield $) .[\alpha]_{\mathrm{D}}^{23}-17.6^{\circ}\left(c=1.53, \mathrm{CHCl}_{3}\right)$. IR $v_{\text {max }} \mathrm{cm}^{-1}: 3450,1740,1437,1375,1245 .{ }^{1} \mathrm{H}-\mathrm{NMR}$ $\left(\mathrm{CDCl}_{3}\right) \delta: 1.16-2.51(7 \mathrm{H}, \mathrm{m}), 2.04(3 \mathrm{H}, \mathrm{s}), 2.27(1 \mathrm{H}, \mathrm{d}$, $\mathrm{d}, J=15.3,8.9 \mathrm{~Hz}), 2.41(1 \mathrm{H}, \mathrm{d}, \mathrm{d}, J=15.4,6.4 \mathrm{~Hz}), 2.61$ $(1 \mathrm{H}, \mathrm{m}), 3.68(3 \mathrm{H}, \mathrm{s}), 3.63-3.83(2 \mathrm{H}, \mathrm{m}), 4.99(1 \mathrm{H}, \mathrm{d}, \mathrm{d}, \mathrm{d}$, $J=7.2,2.6,2.5 \mathrm{~Hz})$. HR-MS $(m / z): 267.1301(\mathrm{M}+\mathrm{Na})^{+}$. Calcd. for $\mathrm{C}_{12} \mathrm{H}_{20} \mathrm{O}_{5} \mathrm{Na}$ : 267.1208. Similarly, $(+)-12 \mathrm{~b}$, $[\alpha]_{\mathrm{D}}^{23}+17.8^{\circ}\left(c=1.23, \mathrm{CHCl}_{3}\right)$, was prepared from $(-)-5$.

(IR,2S,3S)-Methyl 3-acetoxy-2-formylmethyl-1-cyclopentaneacetate $(\mathbf{1 2 c})$. To a solution of $(-)-\mathbf{1 2 b}(80 \mathrm{mg}, 0.33$ mmol) in $10 \mathrm{ml}$ of $\mathrm{CH}_{2} \mathrm{Cl}_{2}$ was added pyridinium dichromate (PDC, $0.25 \mathrm{~g}, 0.66 \mathrm{mmol}$ ) under $\mathrm{N}_{2}$. The mixture was stirred at room temperature overnight. After a general workup, the product was chromatographed on $\mathrm{SiO}_{2}$ to give aldehyde $12 \mathrm{c}$ (49 mg, 62\% yield). IR $v_{\max }$ $\mathrm{cm}^{-1}: 2720,1735,1720,1435,1240,1020 .{ }^{1} \mathrm{H}-\mathrm{NMR}$ $\left(\mathrm{CDCl}_{3}\right) \delta: 1.26-2.50(8 \mathrm{H}, \mathrm{m}), 2.04(3 \mathrm{H}, \mathrm{s}), 2.61-2.76(23 \mathrm{H}$, $\mathrm{m}), 3.68(3 \mathrm{H}, \mathrm{s}), 4.84(\mathrm{lH}, \mathrm{d}, \mathrm{d}, \mathrm{d}, J=7.3,3.7,3.7 \mathrm{~Hz})$, $9.77(1 \mathrm{H}, \mathrm{t}, J=1.8 \mathrm{~Hz})$.

(IR,2S,3S)-Methyl 3-acetoxy-2-(2Z-pentenyl)-1-cyclopentaneacetate (13). To a stirred solution of $(1 R, 2 S, 3 S)-\mathbf{1 2} \mathrm{c}$ $(67 \mathrm{mg}, 0.28 \mathrm{mmol})$ was added a salt-free solution of propylidenetriphenylphosphorane, which had been prepared from propyltriphenylphosphonium bromide $(1.08 \mathrm{~g}$, $2.8 \mathrm{mmol}$ ), in $5 \mathrm{ml}$ of benzenc. After stirring for $1 \mathrm{hr}$ at room temperature, the reaction mixture was quenched with acetic acid, and then evaporated to a small volume. The residue was chromatographed to give $48 \mathrm{mg}$ ( $64 \%$ yield) of acetate 13. IR $v_{\max } \mathrm{cm}^{-1}: 1740,1655,1440,1248,1020$. ${ }^{1} \mathrm{H}-\mathrm{NMR}\left(\mathrm{CDCl}_{3}\right) \delta: 0.96(3 \mathrm{H}, \mathrm{t}, J=7.5 \mathrm{~Hz}), 1.30-2.21$ $(9 \mathrm{H}, \mathrm{m}), 2.01(3 \mathrm{H}, \mathrm{s}), 2.24(1 \mathrm{H}, \mathrm{d}, \mathrm{d}, J=15.4,9.3 \mathrm{~Hz}), 2.42$ $(1 \mathrm{H}, \mathrm{d}, \mathrm{d}, J=15.3,6.2 \mathrm{~Hz}), 2.63(1 \mathrm{H}, \mathrm{d}, \mathrm{d}, \mathrm{t}, J=17.6,9.5$, $6.8 \mathrm{~Hz}), 3.67(3 \mathrm{H}, \mathrm{s}), 4.90(1 \mathrm{H}, \mathrm{d}, \mathrm{d}, \mathrm{d}, J=6.5,3.2,3.2 \mathrm{~Hz})$, $5.26-5.48(2 \mathrm{H}, \mathrm{m})$.

$(+)-(1 R, 2 S, 3 S)-3-H y d r o x y-2-(2 Z$-pentenyl $)-1-c y c l o-$ pentaneacetic acid (1a). To a solution of acetate $13(36 \mathrm{mg}$, $0.13 \mathrm{mmol}$ ) in $1.3 \mathrm{ml}$ of $\mathrm{MeOH}$ and $0.7 \mathrm{ml}$ of water was added $1 \mathrm{ml}$ of $1 \mathrm{~N}$ aq. $\mathrm{NaOH}$. After stirring at $40^{\circ} \mathrm{C}$ for several hours, the reaction solution was concentrated, acidified with dilute $\mathrm{HCl}$ and extracted with $\mathrm{CHCl}_{3}$. The extract was cried over $\mathrm{MgSO}_{4}$ and evaporated in vacuo. The residue was chromatographed on $\mathrm{SiO}_{2}$ to give $(+)$ cucurbic acid $(\mathbf{1 a}, 25 \mathrm{mg}, 87 \%$ yield $) .[\alpha]_{\mathrm{D}}^{23}+24.0^{\circ}$ $\left(c=0.27, \mathrm{CHCl}_{3}\right) . \mathrm{IR} v_{\max } \mathrm{cm}^{-1}: 3370,2650,1708,1403$, $1280,1065 .{ }^{1} \mathrm{H}-\mathrm{NMR}\left(\mathrm{CDCl}_{3}\right) \delta: 0.97(3 \mathrm{H}, \mathrm{t}, J=7.6 \mathrm{~Hz})$, $1.29-2.14(9 \mathrm{H}, \mathrm{m}), 2.24(1 \mathrm{H}, \mathrm{d}, \mathrm{d}, J=15.4,9.3 \mathrm{~Hz}), 2.45$ 
$(1 \mathrm{H}, \mathrm{d}, \mathrm{d}, J=15.4,6.4 \mathrm{~Hz}), 2.68(1 \mathrm{H}, \mathrm{m}), 4.02(1 \mathrm{H}, \mathrm{d}, \mathrm{d}$, d, $J=5.4,2.7,2.7 \mathrm{~Hz}), 5.30-5.52(2 \mathrm{H}, \mathrm{m})$. Similarly, $(-)-1 \mathrm{a},[\alpha]_{\mathrm{D}}^{23}-25.0^{\circ}\left(c=0.31, \mathrm{CHCl}_{3}\right)$, was prepared from $(-)-5$.

(+)-(IR,2S,3S)-Methyl 3-hydroxy-2-(2Z-pentenyl)-Icyclopentaneacetate: methyl cucurbate (1) . A solution of $(+)-1 \mathrm{a}(17 \mathrm{mg}, 0.08 \mathrm{mmol})$ in $1 \mathrm{ml}$ of dry ether was treated with diazomethane. After evaporating, the residue was chromatographed on $\mathrm{SiO}_{2}$ to give $(+)$-methyl ester $\mathbf{1 b}$ (19 mg, 100\% yield). $[\alpha]_{\mathrm{D}}^{23}+12.0^{\circ}\left(c=0.94, \mathrm{CHCl}_{3}\right)$. IR $v_{\max } \mathrm{cm}^{-1}: 3400,3000,1738,1435,1168,1013 .{ }^{1} \mathrm{H}-\mathrm{NMR}$ $\left(\mathrm{CDCl}_{3}\right) \delta: 0.97(3 \mathrm{H}, \mathrm{t}, J=7.5 \mathrm{~Hz}), 1.26-2.13(10 \mathrm{H}, \mathrm{m})$, $2.21(1 \mathrm{H}, \mathrm{d}, \mathrm{d}, J=9.3,15.1 \mathrm{~Hz}), 2.68(1 \mathrm{H}, \mathrm{m}), 3.67(3 \mathrm{H}$, s), $4.01(1 \mathrm{H}, \mathrm{m}), 5.31-5.51(2 \mathrm{H}, \mathrm{m})$.HR-MS $(\mathrm{m} / \mathrm{z}): 227.1645$ $\left(\mathrm{M}+\mathrm{H}^{+}\right)$. Calcd. for $\mathrm{C}_{23} \mathrm{H}_{23} \mathrm{O}_{3}$ : 227.1646. Similarly, (-)-enantiomer $\mathbf{1 b},[\alpha]_{\mathrm{D}}^{23}-11.0^{\circ}\left(c=1.31, \mathrm{CHCl}_{3}\right)$, was prepared from $(-)-5$.

(-)-(IR,2S,3R)-Methyl 3-acetoxy-2-(2-triphenylmethoxyethyl)-1-cyclopentaneacetate (14a). A mixture of (t)-11b (119 mg, $0.27 \mathrm{mmol}), \mathrm{Ac}_{2} \mathrm{O}(0.08 \mathrm{~g}, 0.80 \mathrm{mmol})$, pyridine $(0.13 \mathrm{~g}, 1.60 \mathrm{mmol})$ and $10 \mathrm{mg}$ of DMAP in $1 \mathrm{ml}$ of dry $\mathrm{CH}_{2} \mathrm{Cl}_{2}$ was stirred at room temperature overnight. The mixture was concentrated to a small volume and chromatographed on $\mathrm{SiO}_{2}$ to give (-)-14a (131 mg, 100\% yield). $[\alpha]_{\mathrm{D}}^{23}-9.1^{\circ}\left(c=1.27, \mathrm{CHCl}_{3}\right) . \mathrm{IR} v_{\max } \mathrm{cm}^{-1}: 1740$ $1600,1450,1243,1070,705 .{ }^{1} \mathrm{H}-\mathrm{NMR}\left(\mathrm{CDCl}_{3}\right) \delta$ : $1.47-2.52(8 \mathrm{H}, \mathrm{m}), 1.96(3 \mathrm{H}, \mathrm{s}), 2.24(1 \mathrm{H}, \mathrm{d}, \mathrm{d}, J=16.0$, $11.8 \mathrm{~Hz}), 2.42(1 \mathrm{H}, \mathrm{d}, \mathrm{d}, J=15.8,3.8 \mathrm{~Hz}), 3.09(1 \mathrm{H}, \mathrm{m})$, $3.66(3 \mathrm{H}, \mathrm{s}), 5.01(1 \mathrm{H}, \mathrm{d}, \mathrm{d}, \mathrm{d}, J=5.8,5.8,2.3 \mathrm{~Hz}), 7.02-7.45$ $(15 \mathrm{H}, \mathrm{m})$. Anal. Found: C, 76.35; H, 7.23. Caled. for $\mathrm{C}_{31} \mathrm{H}_{34} \mathrm{O}_{5}: \mathrm{C}, 76.52 ; \mathrm{H}, 7.04 \%$.

(+)-(lR,2S,3R)-Methyl 3-acetoxy-2-(2-hydroxyethyl)I-cyclopentaneacetate (14b). Detritylation of (-)-14a (230 $\mathrm{mg}, 0.47 \mathrm{mmol}$ ) by the same method as that for the case of $(+)-12$ a gave $(+)-14 b(75 \mathrm{mg})$ in a $66 \%$ yield, $[\alpha]_{\mathrm{D}}^{23}$ $+7.2^{\circ}\left(c=1.49, \mathrm{CHCl}_{3}\right)$. IR $v_{\max } \mathrm{cm}^{-1}: 3450,1737,1439$, $1377,1248,1020 .{ }^{1} \mathrm{H}-\mathrm{NMR}\left(\mathrm{CDCl}_{3}\right) \delta: 1.52-2.63(9 \mathrm{H}, \mathrm{m})$, $2.05(3 \mathrm{H}, \mathrm{s}), 2.29(1 \mathrm{H}, \mathrm{d}, \mathrm{d}, J=15.3,10.9 \mathrm{~Hz}), 3.67(2 \mathrm{H}$, $\mathrm{t}, J=6.6 \mathrm{~Hz}), 3.69(3 \mathrm{H}, \mathrm{s}), 5.23(1 \mathrm{H}, \mathrm{d}, \mathrm{d}, \mathrm{d}, J=5.4,5.4$, $2.1 \mathrm{~Hz})$. HR-MS $(m / z): 245.1413(\mathrm{M}+\mathrm{H})^{+}$. Calcd. for $\mathrm{C}_{12} \mathrm{H}_{21} \mathrm{O}_{5}: 245.1388$.

(IR,2S,3R)-Methyl 3-acetoxy-2-formylmethyl-1-cyclopentaneacetate (14c). Oxidation of $(+)-14 b \quad(80 \mathrm{mg}$, $0.33 \mathrm{mmol}$ ) by the same method as that for the case of $(-)-12 b$ gave aldehyde $14 \mathrm{c}(49 \mathrm{mg})$ in a $62 \%$ yield. IR $v_{\max }$ $\mathrm{cm}^{-1}: 2730,1738,1243,1021 .{ }^{1} \mathrm{H}-\mathrm{NMR}\left(\mathrm{CDCl}_{3}\right) \delta$ : $1.46-2.75(10 \mathrm{H}, \mathrm{m}), 2.03(3 \mathrm{H}, \mathrm{s}), 3.68(3 \mathrm{H}, \mathrm{s}), 5.23(1 \mathrm{H}$, $\mathrm{m}), 9.77(1 \mathrm{H}, \mathrm{s})$.

(1R,2S,3R)-Methyl3-acetoxy-2-(2Z-pentenyl)-1-cyclopentaneacetate (15). A Wittig reaction with $14 \mathrm{c}(18 \mathrm{mg}$, $0.07 \mathrm{mmol}$ ) by a similar method as that for the case of $\mathbf{1 2 c}$ gave $15(10 \mathrm{mg})$ in a $49 \%$ yield. IR $v_{\max } \mathrm{cm}^{-1}: 1738,1655$,
$1438,1375,1240,1020 .{ }^{1} \mathrm{H}-\mathrm{NMR}\left(\mathrm{CDCl}_{3}\right) \delta: 0.95(3 \mathrm{H}, \mathrm{t}$, $J=7.5 \mathrm{~Hz}), 1.49-2.62(11 \mathrm{H}, \mathrm{m}), 2.04(3 \mathrm{H}, \mathrm{s}), 2.30(1 \mathrm{H}, \mathrm{d}$, d, $J=15.3,4.2 \mathrm{~Hz}), 3.68(3 \mathrm{H}, \mathrm{s}), 5.15(1 \mathrm{H}, \mathrm{m}), 5.23-5.44$ $(2 \mathrm{H}, \mathrm{m})$.

(-)-(lR,5R,8S)-8-(2Z-Pentenyl)-2-oxabicyclo[3.2.I]octan-3-one (16). Hydrolysis of $15(11 \mathrm{mg}, 0.04 \mathrm{mmol})$ in a similar manner to that for the case of 13 gave $(-)-16$ $(7 \mathrm{mg})$ in a $95 \%$ yield. $[\alpha]_{\mathrm{D}}^{23}-71.0^{\circ}\left(c=0.29, \mathrm{CHCl}_{3}\right)$. IR $v_{\max } \mathrm{cm}^{-1}: 3000,1738,1655,1375,1217,1140,1000$. ${ }^{1} \mathrm{H}-\mathrm{NMR}\left(\mathrm{CDCl}_{3}\right) \quad \delta: 0.95(3 \mathrm{H}, \mathrm{t}, J=7.6 \mathrm{~Hz}), 1.61-$ $2.40(11 \mathrm{H}, \mathrm{m}), 2.74(1 \mathrm{H}, \mathrm{m}), 4.59(1 \mathrm{H}, \mathrm{m}), 5.31-5.54$ $(2 \mathrm{H}, \mathrm{m})$. HR-MS $(\mathrm{m} / \mathrm{z}): 217.110(\mathrm{M}+\mathrm{Na})^{+}$. Calcd. for $\mathrm{C}_{12} \mathrm{H}_{18} \mathrm{O}_{2} \mathrm{Na:} 217.1204$. Similarly, $(+)-16,[\alpha]_{D}^{23}+68.9^{\circ}$ $\left(c=0.52, \mathrm{CHCl}_{3}\right)$, was prepared from $(-)-\mathbf{1 4 b}$.

Bioassay. A group of twenty lettuce seeds each (cv. Great Lakes) was placed in $4 \mathrm{~cm}$ petri dishes, which contained a double layer of filter paper moistened with $2 \mathrm{ml}$ of a test solution. Incubation was conducted at $25^{\circ} \mathrm{C}$ under continuous white light for $140 \mathrm{hr}$, and the root lengths was then measured.

Acknowledgment. The authors thank Zeon Japan Co., Ltd. for their provision of ( \pm )-methyl jasmonate. We are also grateful to Meito Sangyo Co., Ltd. for their provision of Lipase MY.

\section{References}

1) H. Fukui, K. Koshimizu, S. Usuda and Y. Yamazaki, Agric. Biol. Chem., 41, 175 (1977).

2) D. C. Aldridge, S. Galt, D. Giles and W. B. Turner, J. Chem. Soc. (C), 1971, 1623; H, Fukui, K. Koshimizu, S. Usuda and Y. Yamazaki, Agric. Biol. Chem., 41, 175 (1977).

3) J. Ueda, J. Kato, H. Yamane and N. Takahashi, Physiol. Plant., 52, 305 (1981); H. Yamane, J. Sugawara, Y. Suzuki, E. Shimamura and N. Takahashi, Agric. Biol. Chem., 44, 2857 (1980).

4) T. Oritani, K. Yamashita, J. Synth. Org. Chem. Jpn., 41, 1054 (1983); K. Yamamoto, T. Nishoka and J. Oda, Tetrahedron Lett., 29, 1717 (1988).

5) H. Tanaka and S. Torii, J. Org. Chem., 40, 462 (1975).

6) B. Maurer and A. Hauser, Helv. Chim. Acta, 65, 462 (1982).

7) T. Kitahara, K. Miura, Y. Warita, Y. Takagi and K. Mori, Agric. Biol. Chem., 51, 1129 (1987).

8) W. H. Kruizinga, B. Strijtveen and R. M. Kellogg, J. Org. Chem., 46, 4321 (1981).

9) O. Mitsunobu, Synthesis, 1981, 1.

10) Y. Torisawa, H. Okabe and S. Ikegami, Chem. Lett., $1984,1555$.

11) M. Schlosser, G. Müller and K. F. Christmann, Angew. Chem., 78, 677 (1966). 